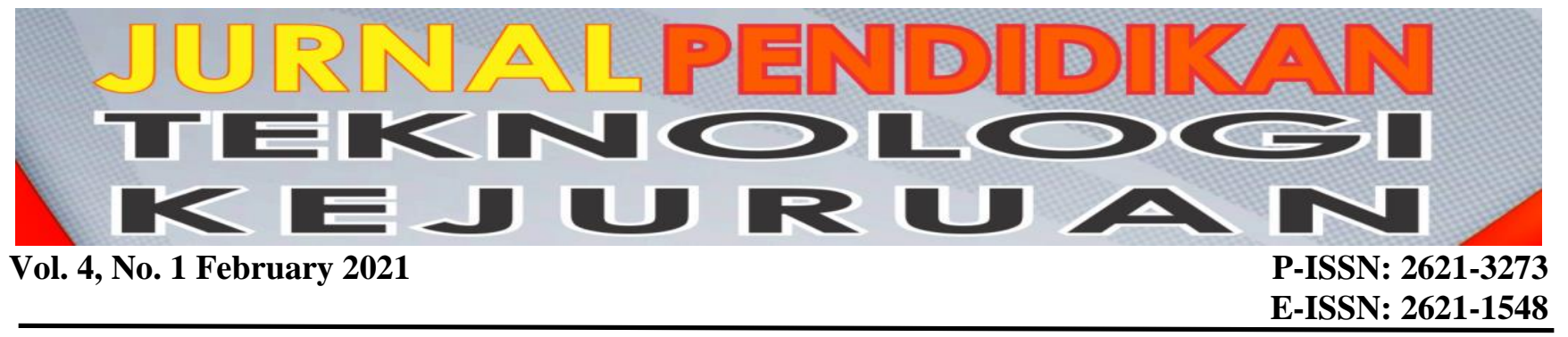

\title{
Design of E-Module Based on Discovery Learning in Basic Boga Students of Class X Tata Boga in SMK Negeri 1 Beringin
}

\author{
Lulu Fajarwati ${ }^{1^{*}}$ and Agusti Efi ${ }^{2}$ \\ ${ }^{12}$ Faculty of Tourism and Hospitality, Universitas Negeri Padang \\ *Corresponding author, e-mail: lulufajarwati28@gmail.com ${ }^{1}$
}

\begin{abstract}
The purpose of this research is to produce a valid e-modules based on discovery learning, and effective in basic food subjects. This e-modules based on discovery learning is designed to improve student's understanding so that it can improve students learning outcomes. The method in this study uses Research and Development (R\&D) with 4-D development procedures (Define, Design, Develop, Disseminate). The data of analysis technique uses descriptive analysis techniques to describe the validity, practicality, and effectiveness of e-modules based on discovery learning. The results obtained of this development research: The validity of e-modules based on discovery learning is declared valid on the media and material aspects. The practicality of e-modules based on discovery learning from teacher and student responses is stated to be very practical. The effectiveness of e-modules based on discovery learning is stated to be effective in improve to learn the outcomes. Based on the findings of this study it is concluded that the emodules based on discovery learning is valid, practical, and effective to be used as a learning aid in basic food subjects.
\end{abstract}

Keyword: e-modul, discovery learning

\section{INTRODUCTION}

The development of science and technology that is so fast and the development of communication systems that are increasingly fast causing changes and advances in various aspects of life. The rapid advancement of technology and information has brought changes to life patterns as well as in the world of education (Wahid, 2016). With these changes and advances, an adjustment attitude is required to always learn so as not to be left behind with the ever-evolving technological pace.

The development of science and technology further encourages renewal efforts in utilizing technological results in the teaching and learning process. Creating an interesting and fun learning process can be done by utilizing technology science which is used as teaching material to support the learning process (Lestari, 2015). Therefore, teachers are expected to have a variety of learning resources and be able to cultivate the teaching and learning process with the aim of increasing student activity and learning outcomes.

Teaching materials are very important for teachers and students in learning activities. Teachers will experience difficulties in increasing the effectiveness of learning without teaching materials and students will also experience difficulties in learning without teaching materials. This is added to if the teacher explains the learning material is not interesting, too fast and unclear. Therefore, teaching materials are very important to be developed in an effort to improve the quality of learning. Basically, teaching materials have several roles for teachers, students, and in learning activities. The development of teaching materials is carried out by a teacher to solve learning problems by paying attention to targets or students and also adjusting the competencies that must be achieved (Sungkono, 2009).

Teaching materials have many kinds / forms. One of the easiest forms of teaching materials for teachers to make is printed materials, such as modules. Modules are teaching materials arranged systematically and attractively which include material content, methods and evaluation that can be used independently to achieve the expected competencies (Anwar, 2010). The use of modules in learning can help facilitate student learning activities to achieve learning goals. Based on the results of observations and interviews that were conducted on February 18, 2020 at SMK 
Negeri 1 Beringin, Lubuk Pakam City, Deli Serdang Regency, North Sumatra Province, in class X Catering, there is a Basic Culinary subject. Basic food subjects have the aim of developing cognitive, psychomotor and affective so that students are expected to be able to understand, master and practice. Basic Catering subjects are a form of productive learning in Vocational High Schools that apply theory and practice and require reasoning.

In accordance with the 2013 curriculum syllabus, this subject consists of four basic competencies in odd semesters that must be studied by students, namely, food processing equipment, pieces of food ingredients, food processing techniques, and basic spices and their derivatives in Indonesian cuisine. These four basic competencies must be followed or studied by class $\mathrm{X}$ students thoroughly, because they are the basic knowledge for students to practice all types of food and beverage processing in advanced subjects.

E-module is a digital module that can be read on a computer, smartphone or other digital reader. Electronic modules (e-modules) can be developed as teaching materials that can be studied independently. The use of e-modules in learning can help facilitate student learning activities to achieve learning goals. In order to produce an e-module that is able to increase user motivation, the e-module must include the characteristics it needs. The characteristics of emodules that must be considered include: being able to teach yourself, not depending on other parties (selfintructional), the integrity of the scope of learning material (self-contained), independent of other media (stand alone), interactive adaptive to the development of science and technology (Adaptive), and friendly / familiar with the wearer (user friendly). (Ministry of National Education, 2008).

E-modules are made based on a comprehensive and systematic learning program and are designed for independent learning systems. It contains objectives, teaching materials and learning activities, and evaluation. Therefore, the coverage of the material in the module is more focused and measured, and it is more concerned with the learning activities of the reader, and all of the presentation is conveyed through communicative language. Learning using e-modules can make students more active, understand more and students can study e-modules at any time (independent study).

Discovery learning-based e-modules are an innovative learning media that will be developed. This e-module will contain material that will be conveyed to readers, especially students with the concept of discovery learning learning models. Discovery learning-based e-modules do not only contain text, but also images and videos which are expected to increase the enthusiasm of learning from students. By designing and making e-modules using the discovery learning model, it is hoped that students can explore their abilities and foster students' creativity and curiosity. So that indirectly students become more enthusiastic in participating in the teaching and learning process and the knowledge that students get is more attached to their memory.

The impact of the Covid-19 pandemic on education has been recognized by the UNESCO education organization. The activities of nearly 300 million students worldwide have been affected by this pandemic. The most dreaded impact is the long-term effect because students will automatically feel the delay in the ongoing educational process. Tam and El Azar (2020) stated that the corona virus pandemic caused three fundamental changes in global education. First, changing the way millions of people are educated. Second, new solutions for education that can bring about much-needed innovation. Third, the existence of a digital divide causes new shifts in educational approaches and can widen the gap. This shows that Covid-19 has accelerated the transformation of education. In a very short time, the whole world changed the conventional face-to-face learning pattern in schools to become Distance Learning (PJJ) which relies heavily on technology.

The e-module design is expected to contribute positively to students and teachers in terms of the availability of teaching materials, making students more active and creative. With the development of emodule based on discovery learning with Android, it is hoped that students will be able to understand, link, and apply basic learning concepts using reasoning so that students can learn independently, do not depend on the teacher, and the teacher only helps guide and direct. The availability of this e-module is also expected to help improve students 'understanding of the subject matter, increase students' interest in Basic Food subjects, and be able to complete the evaluation provided in the module to see how far students understand the material being taught.

This is reinforced by the results of research by Dewi Nur Muslimah (2019) which states that using discovery learning-based e-modules can improve student learning outcomes on the basic competencies of manual coupling and transmission, and the results of research by Denanda Brigenta, et al (2017) state that the results of students' conceptual understanding 
In learning shows an increase after using discovery learning-based e-modules, the following problems can be identified:

a. Unavailability of modules in Basic Catering subjects.

b. Basic Food Learning still uses the lecture method and power point as a medium of learning.

c. Teacher centered learning is not student centered (student centered learning).

d. Limited time during learning activities in delivering Basic Food learning materials.

Based on the problem identification above, the problem formulation in this study is how the level of validity, practicality, and effectiveness of discovery learning-based e-modules for class X SMK Negeri 1 Beringin students were designed. The purpose of this study was to produce a discovery learning-based EModule for the X grade students of SMK Negeri 1 Beringin that was valid, practical, and effective.

\section{A. Learning Module}

\section{Definition of Learning Module}

The learning module is a program unit in teaching and learning activities in the classroom that is studied by students themselves individually or taught by students to themselves (self-instructional) (Winkel, 2009). Another definition of module is a teaching material with a complete unity, consisting of a series of activities in learning, which can concretely provide effective learning outcomes in achieving goals in learning that have been clearly and specifically formulated in the module (Mbulu, 2010).

According to the Ministry of National Education (2010), the definition of a module is a learning tool or tool that contains materials, methods, limitations, and ways of evaluating which are designed systematically and attractively to achieve the expected competencies according to the level of complexity. Modules are also subject matter that is arranged and presented in writing in such a way that readers are expected to be able to absorb the subject matter themselves. (Daryanto, 2013).

Based on the description of the understanding of the module by several experts, it can be concluded that the module is a teaching material prepared with the aim of helping students to be more motivated to learn and helping students to learn at any time independently, and as a reference for students for the stages of learning to be discussed. . The module that will be developed is a guideline to assist students in understanding the basics of food processing in Basic Culinary subjects. With the existence of a good Basic Food module, it is hoped that it can help students to further improve the efficiency and effectiveness of learning, both time, funds, facilities, and energy.

\section{Module Characteristics}

Characteristics of learning modules that are adapted to the guidelines for writing in modules issued by the Directorate of Vocational Education, Directorate General of Primary and Secondary Education, Ministry of National Education, 2003 (Lestari, 2013), are as follows:

a. Self instructional, is able to make students learn independently. Through this module students are able to learn independently. To fulfill a character in Self Instructional

b. Self Contained, which is the entire learning material from one competency unit or sub competency of learning that is studied in one module as a whole. The purpose of this concept is to provide opportunities for students to study the learning material thoroughly and get maximum value, because the material is packaged into a single unit that makes it easier for students to learn learning material.

c. Stand Alone (stand alone), that is, the module is developed independently of any other media or does not have to be used together with other learning media. By using modules, students are not dependent on learning media and must use other media to study the material to be studied and / or do assignments in the module.

d. Adaptive, the module should have high adaptive power to the development of science and technology that has been developed. Modules can be said to be adaptive if they can adapt their development to science and technology, and are flexible to use. An adaptive module is if the content of the learning material can be used up to a certain time.

e. User friendly, the module should be friendly to students. Every way of use and exposure to information contained in the module is shown to be easy for students to understand and can help students understand the content of the material presented in the module and make friends with students, including the ease with which students respond to the module, access according to the desired material . The use of language that is very simple and easy to understand by students and using terms that are generally used so that students can easily understand the material in the module is a form of user friendly.

\section{Function and Purpose of Learning Module}

The module is a learning tool or tool that contains materials, methods, and ways of evaluating which are designed systematically and attractively (Syafitri \& Festiyed, et al., 2019). According to Mulyasa (2010), 
the main objective of the module is to increase the efficiency and effectiveness of learning, both time, facilities, and manpower to achieve optimal goals. In addition, the module is also made with the aim that students can learn independently as described by Suparman (2014), learning independence is the nature and attitude and ability of students to carry out learning activities independently or with the help of others based on their own motivation to master. a certain competence so that it can be used to solve the problems it faces.

Modules in the Basic Catering subject are also expected to cover all the functions and objectives of the module. With the Basic Food module, it is hoped that it can help the learning process and students can learn independently according to their own abilities in understanding the module material and can assess themselves so that students are motivated to discuss which parts are not yet understood.

\section{B. E-Learning Module}

\section{Definition of E-Learning Module}

Modules are teaching materials that are specially prepared and systematically designed based on a specific curriculum which is packaged into the smallest learning unit (modular) that learners can use independently to achieve certain predetermined learning goals. Along with the development of information and communication technology the demands of 21 st century skills, teaching materials are needed that are in accordance with the conditions of students and the learning strategies used by the teacher. One of the teaching materials that can be developed is an interactive learning module in the form of an electronic module (E-module). Nursito stated that current learning activities emphasize process skills and active learning, so learning media are becoming increasingly important (Kemendikbud, 2017).

An electronic module is an electronic version of a module that has been printed, designed with the necessary software, and can be read through electronic devices such as computers, laptops, tablets or smartphones. E-modules are learning materials that are systematically designed based on a certain curriculum and are packaged in a specific time unit, which is displayed using electronic devices such as computers or androids (Danang, 2015). Meanwhile, according to (Wijayanto, 2014) the electronic module or e-module is a display of information in a book format that is presented electronically using a hard disk, floppy disk, CD or flash disk and can be read using a computer or an electronic book reader.

\section{Electronic Module Characteristics}

Modules as independent learning media have various characteristics. The characteristics of the print module can then be adapted into the electronic module (B.P. Sitepu, 2006). The characteristics of the e-module described by the Ministry of Education and Culture (2017) are as follows:

a. Self instructional, students are able to teach themselves, not depending on other parties.

b. Self contained, all learning material from one unit of competence that is learned is contained in one intact module.

c. Stand alone, the developed module does not depend on other media or does not have to be used together with other media.

d. Adaptive, the module should have high adaptive power to the development of science and technology.

e. User friendly, the module should also meet the familiar rules of being friendly / familiar with the wearer.

f. Be consistent in the use of fonts, spacing, and layout.

g. Delivered using a computer-based electronic media.

h. Utilizing various functions of electronic media so that it is referred to as multimedia.

i. Take advantage of various features available in software applications.

j. Need to be designed carefully (paying attention to the principles of learning)

\section{Principles of Electronic Module Development}

The preparation of learning modules is the process of arranging learning materials that are packaged systematically so that they are ready to be studied by students to achieve competencies or subcompetencies. The preparation or development of learning modules needs to be adapted to existing needs and conditions. The arrangement or development of learning modules that do not pay attention to this causes the learning module to be less usable by students, so that students have difficulty absorbing the knowledge conveyed in the learning module. Just as the use of language at a level that is too high can not be understood by the meaning of the delivery of knowledge or material by students, this problem arises (Daryanto, 2013).

The preparation of learning modules is adjusted to the principles and guidelines that have been established to produce appropriate and quality learning modules. Related to this, there are several principles of emodule development initiated by the Ministry of Education and Culture (2017), namely: 
In general, the electronic module adapts the components contained in the print module, but compared to the print module, the e-module has several advantages. Kemendikbud (2017) explains that e-module has several advantages, namely:

a. Increase student motivation, because every time they do a lesson task is clearly limited and according to ability.

b. After the evaluation, the teacher and students know exactly which modules the students have succeeded in and which parts of the modules they have not succeeded.

c. Lesson material is divided more evenly in one semester.

d. Education is more efficient, because learning materials are arranged according to academic levels.

e. The static presentation in the print module can be changed to be more interactive and more dynamic.

f. Verbalism elements that are too high in the print module can be reduced by presenting a visual element with the use of video tutorials.

E-module has many advantages compared to print modules in general. However, e-modules also have drawbacks. The disadvantages of e-modules include:

a. The development takes a long time and costs a relatively large amount of money.

b. Students in general do not necessarily have high learning discipline.

c. More serious need from the teacher to supervise the learning process and always motivate and consult students.

d. Availability of devices to access it, because emodules can only be accessed using electronic devices in the form of computers or android smartphones. If the device is not available then the e-module cannot be used.

\section{Discovery Learning Based Learning}

One of the learning models that can be done in the teaching and learning process is discovery learning. According to Brunner, discovery learning corresponds to the active search for knowledge by humans and by itself provides good results. Trying on your own to find solutions to problems and the knowledge that accompanies them will result in meaningful knowledge (Trianto, 2007). Discovery is a mental process where students are able to assimilate a concept or principle.

The mental processes in question include: observing, digesting, understanding, classifying, making assumptions, explaining, measuring, making conclusions and so on. With this technique students are left to discover on their own or experience their own mental processes, the teacher only guides and provides instructions. Thus discovery learning is a learning that involves students in the process of mental activities through exchange of opinions, by discussing, reading on their own and trying on their own, so that children can learn on their own (Tumurun, 2016). Sund \& Troubidge stated that discovery when an individual is in volve mainly in using his mental process to mediate (discover) some concept or principle. The discovery process (discovery) occurs when students are involved in the process of discovering a concept or principle (Suprehiningrum, 2013).

So the discovery learning model, a technique, a method that teachers use in learning by expecting students to engage in investigating a relationship, collect data, and use it to find laws or principles that apply to the incident. From the above understanding, it can be concluded that the learning model is a form of teacher strategy that is used as a guide in the learning process by considering the character of subject content, teacher competence and student conditions. This is done to lead students to changes in competence which consist of cognitive, affective and psychomotor aspects.

Discovery learning learning model can also be called learning by finding or discovery because in the process students will be taught some material, then they must be able to develop the material themselves with the material that has been conveyed by the educator. Discovery learning model requires students to be able to think for themselves then they must be able to find general principles and developments.

\section{Android}

Android is an operating system for linux-based mobile devices that includes an operating system, middleware and applications. (Nazruddin Safaat H, 2012) According to Akhmad Dharma Kasman (2016), "Android is an operating system for mobile phones and touchscreen tablet computers based on linux". But along with its development, Android has turned into a platform that is so fast in innovating. This cannot be separated from the main developer behind it, namely Google. Google, which acquired Android, then created a platform. The android platform consists of a Linux-based operating system, a GUI (Graphic User Interface), a web browser and downloadable applications and developers can freely work and create the best and open applications for use by various devices.

To create an Android-based application, a software is needed to make, one of which is Android Studio. Android studio is an application introduced by 
Google for the development of Android Development at the Google I / O 2013 event. Android is an upgrade from Eclipse and is made according to the Java IDE. As a development of Eclipse, Android Studio has many new features compared to the Eclipse IDE. So in terms of use and features, Android Studio has received full support to make it easier for users (Aryani, 2017).

From the description above, it can be concluded that Android is an operating system, middleware and applications made with software so that it can be accessed with the user's cellphone or smartphone.

\section{E. Basic Catering Subjects}

Basic Food is knowledge in the art of processing food which includes the scope of food, knowing kitchen utensils and their use, preparing food processing to serving, basic handling of food processing, cutting food ingredients, basic spices and their derivatives in Indonesian cuisine, sambal in Indonesian food. , food processing techniques, food ingredients used for garnishes, mats and serving containers.

Basic culinary is a very important and fundamental subject in the culinary department at SMK, students are expected to understand well so that they can relate to other culinary subjects. In accordance with the 2013 curriculum, Basic Catering learning is for class $X$ SMK Tata Catering semesters 1 (one) and 2 (two). In the process, learning will not occur if there are no supporting components for the learning process. Where there are three main component categories in the learning process, namely educators, content / material, and students.

\section{F. Conceptual framework}

Based on the background and theoretical studies that have been described, it is further formulated into a conceptual framework. Basic Food Learning at SMKN 1 Beringin is still a teacher center learning with power point learning media used by teachers. There is no adequate teaching material and there are no modules specifically designed with a learning model that suits students' needs for independent learning and can actively involve students in the learning process.

Based on the existing problems, it is necessary to design and manufacture teaching materials in the form of e-modules by collaborating learning models so that students can learn actively and independently. The teaching material to be designed is e-module based on discovery learning in Basic Catering subjects at SMK. The design and creation of emodules is carried out in accordance with the competencies being studied and at the appropriate competencies based on the discovery learning learning model.

It is hoped that the developed e-module can be valid, practical, and effective as a learning material that can improve student learning outcomes and overcome problems in the learning process of Basic Catering subjects. E-module is said to be valid seen from the validation questionnaire data filled out by the respondent. Practically e-module is seen from the use of e-module by teachers and students, while the effectiveness of e-module is seen from the percentage of student success through classical learning completeness and the comparison of the percentage of students' pre-test and post-test scores. The conceptual framework in this study can be described in the picture, as follows:

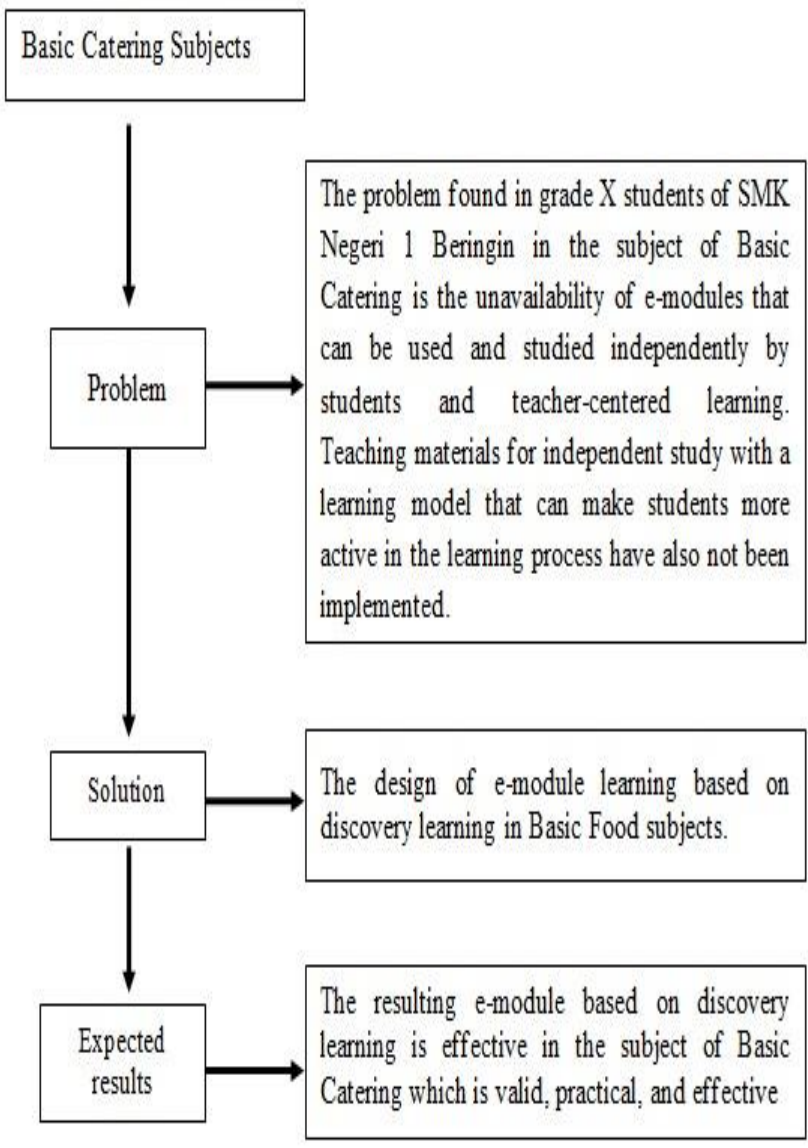

\section{METHOD}

This research is a development research. This study uses an R\&D (research and development) approach. This research method is also defined as a research method used to produce certain products and test the effectiveness of these products (Sugiyono, 2012). Development research in its implementation is an effort to develop or produce and validate a product used in learning (Borg, 2008). Based on this opinion, it can be concluded that research and development $(\mathrm{R} \& \mathrm{D})$ is a research method that aims to develop a 
new product or improve an existing product, so as to produce a product that is superior, effective and efficient than the existing product.

The procedure for developing discovery learningbased learning media in the Basic Catering subject uses the 4-D (four-D) development model developed by Thiagarajan (1974). The development process consists of 4 stages. In details, the module development that will be carried out is described by the chart in the figure.

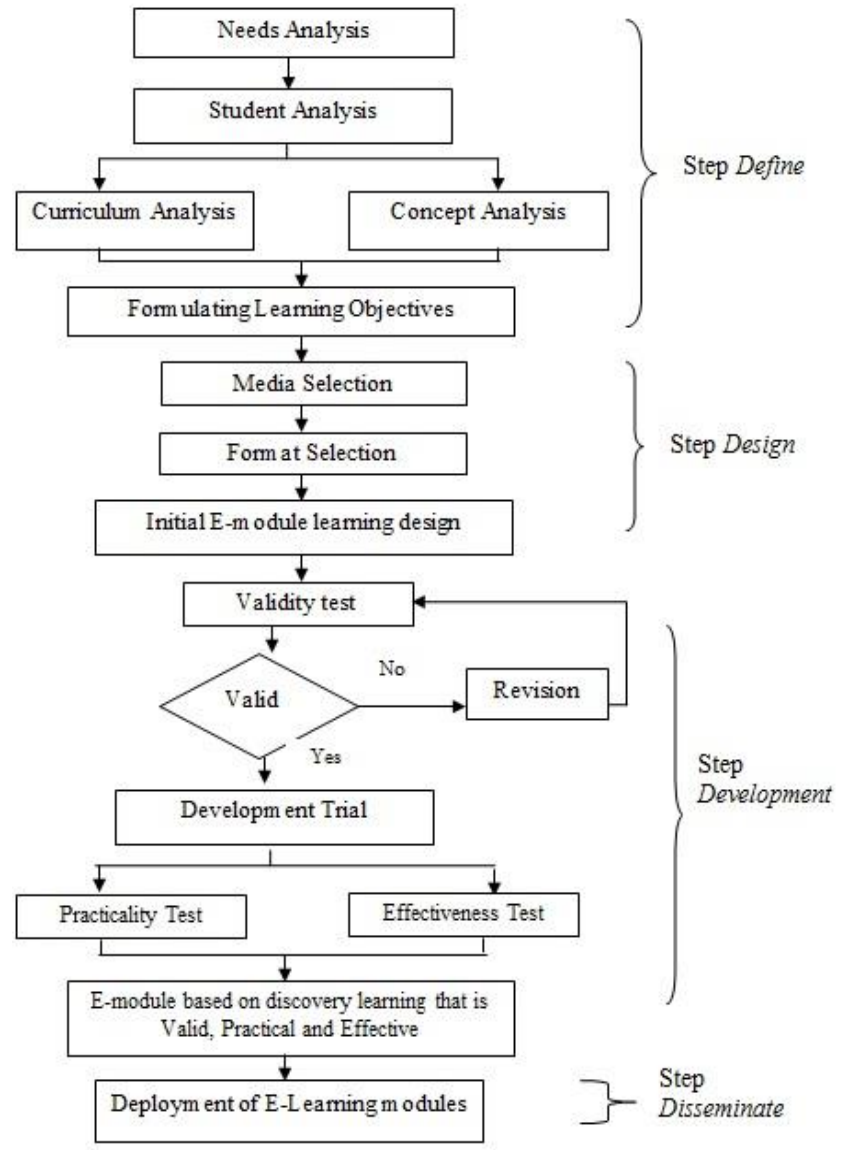

The e-module development model based on discovery learning in the Basic Catering subject uses a development model that refers to the 4-D (four-D) model. This model was chosen because it has a simple and systematic procedure, in accordance with the steps of the development research carried out, and in its development it involves expert judgment so that prior to the trial the developed media has been revised based on the assessment, suggestions and input of experts.

\section{A. RESUlT}

\section{Step Define}

\begin{tabular}{|l|l|l|}
\hline \multicolumn{1}{|c|}{$\begin{array}{c}\text { Basic } \\
\text { Competencies }\end{array}$} & \multicolumn{1}{c|}{$\begin{array}{c}\text { Subject } \\
\text { Matter }\end{array}$} & \multicolumn{1}{c|}{ Indicator } \\
\hline $\begin{array}{l}\text { Describe food } \\
\text { processing } \\
\text { equipment }\end{array}$ & $\begin{array}{l}\text { Food } \\
\text { processing } \\
\text { equipment }\end{array}$ & $\begin{array}{l}\text { 1. Describe the meaning } \\
\text { of food processing } \\
\text { equipment. }\end{array}$ \\
\hline
\end{tabular}

\begin{tabular}{|c|c|c|}
\hline & & $\begin{array}{l}\text { 2. Describes the various } \\
\text { food processing } \\
\text { equipment. } \\
\text { 3. Describe the } \\
\text { functions of various } \\
\text { food processing } \\
\text { equipment. }\end{array}$ \\
\hline $\begin{array}{l}\text { Describe } \\
\text { pieces of food }\end{array}$ & $\begin{array}{l}\text { Pieces of } \\
\text { groceries }\end{array}$ & $\begin{array}{l}\text { 1. Describe the meaning } \\
\text { of pieces of food } \\
\text { 2. Describe the function } \\
\text { of cut food ingredients. } \\
\text { 3. Describe the various } \\
\text { cuts of food. } \\
\text { 4. Explain how to } \\
\text { prepare a good cut of } \\
\text { food. }\end{array}$ \\
\hline $\begin{array}{l}\text { Describe food } \\
\text { processing } \\
\text { techniques }\end{array}$ & $\begin{array}{l}\text { Food } \\
\text { processing } \\
\text { techniques }\end{array}$ & $\begin{array}{l}\text { 1. Describe the meaning } \\
\text { of wet and dry heat } \\
\text { processing techniques. } \\
\text { 2. Describe the types of } \\
\text { wet and dry heat } \\
\text { treatment techniques. } \\
\text { 3. Describe wet hot and } \\
\text { dry heat cooking } \\
\text { methods. } \\
\text { 4. Classify cooking } \\
\text { methods by type. }\end{array}$ \\
\hline $\begin{array}{l}\text { Analyzing the } \\
\text { basic spices } \\
\text { and their } \\
\text { derivatives in } \\
\text { Indonesian } \\
\text { cuisine }\end{array}$ & $\begin{array}{l}\text { Basic spices } \\
\text { and } \\
\text { derivatives } \\
\text { in } \\
\text { Indonesian } \\
\text { cuisine }\end{array}$ & $\begin{array}{l}\text { 1. Explain the notion of } \\
\text { spices in Indonesian } \\
\text { cuisine } \\
\text { 2. Explain the benefits } \\
\text { of basic seasonings in } \\
\text { Indonesian cuisine } \\
\text { 3. Classify spices based } \\
\text { on their origin in } \\
\text { Indonesian cuisine } \\
\text { 4. Explains how to } \\
\text { make basic spices in } \\
\text { Indonesian cuisine }\end{array}$ \\
\hline
\end{tabular}

The formulation of learning objectives is intended to determine the materials developed in the e-module learning. This stage begins with analyzing the basic competencies, then outlining the learning objectives followed by describing the learning material that must be mastered by students. The basic competencies to be studied are food processing techniques because these basic competencies must be mastered thoroughly by students as a requirement to be able to carry out processing practices in practical subjects and are expected to meet the standard rules set by the school so that the desired goals can be achieved.

\section{Step Design}

This initial design is an e-module design based on discovery learning using android which must be done before being validated and then tested. The characteristics of the e-module developed contain text, images, and videos that help students understand 
the material. The e-module developed is also structured based on the discovery learning-based learning model syntax which will also be used to support the class with the learning process using the discovery learning model.

At this stage, the preparation of an e-module display design framework is carried out which includes the home menu which is the main menu of the media, the material menu, the evaluation menu which contains questions to test the student's ability to the material presented in the media. The following is the result of the e-module design which consists of the following components:

a. The start menu page contains the name of the application as well as the name of the subject being developed. Then in this opening page there is also a "start" navigation which will direct the user to the home page.

b. Home menu page, there are several navigation options from this page, namely home, instructions, introduction, KI \& KD, concept map, learning activities, glossary, bibliography, profile and exit navigation.

c. The manual menu page is a page that contains instructions for using discovery learning-based emodule applications.

d. The introductory menu page is a page that contains an explanation of the contents of the e-module.

e. The KI and KD menu pages are pages that contain core competencies, basic competencies, and indicators on basic food subjects for one semester.

f. The concept map page is a page that contains a chart of the material to be studied in the e-module.

g. The learning activity page is a page that contains basic food learning activities, including instructions for learning activities, materials, videos, learning activities, and tests.

h. Learning activity menu page.

i. The glossary menu page is a page that contains foreign terms found in basic food learning materials.

j. The bibliography menu page is a page that contains learning material resources contained in the -e-module.

$\mathrm{k}$. The profile menu page is a page that contains a profile about the author.

\section{Step Development}

\section{a. Validity Test Data}

The results of the analysis of the validity test to media experts obtained a validation value of $0.86>0.61$, so e-module learning based on discovery learning is categorized as valid. Furthermore, the validation results from material experts obtained a validation value of $0.88>0.61$, which means that the material on discovery learning-based e-module is categorized as valid.

\section{b. Reliability Test Data}

The results of calculations with the help of SPSS version 20 obtained a Cronbach's Alpha value for media experts of 0.770 which indicates that the emodule reliability criteria are at high criteria. Furthermore, the results of calculations by material experts obtained Cronbach's Alpha value of 0.703 with high criteria. From the results of these data calculations, discovery learning-based e-module media is categorized as reliable.

c. Practicality Test Data

Based on the results of the teacher's response about the practicality of using e-modules in the Basic Culinary subject, an average of $88.57 \%$ was obtained with the very practical category. Thus based on the teacher's response the e-module developed is of very practical value. The results of student responses to the use of e-modules obtained an average of $86.67 \%$ with the very practical category. Thus based on student responses the e-module developed is of very practical value. This shows that the e-module developed makes it easy for teachers and helps students understand learning material.

d. Effectiveness Test Data

The gain score is seen from the increase in student learning outcomes after the pretest and posttest. Ngain score is carried out with the aim of the effectiveness of using a method or treatment in the pretest posttest design (experimental design) research group and control group research. From the recapitulation of student learning outcomes with an average gain score of 0.64 which is in the medium category, it is concluded that e-module based on discovery learning is declared effective.

\section{Step Dissemination}

The gain score is seen from the increase in student learning outcomes after the pretest and posttest. Ngain score is carried out with the aim of the effectiveness of using a method or treatment in the pretest posttest design (experimental design) research group and control group research. From the recapitulation of student learning outcomes with an average gain score of 0.64 which is in the medium category, it is concluded that e-module based on discovery learning is declared effective.

\section{B. Discussion}

The design of e-module learning based on discovery learning on the subject of Basic Catering is a series of processes or activities carried out to produce 
discovery learning-based e-modules based on development theory. The purpose of designing discovery learning-based e-modules is to produce discovery learning-based e-modules that are valid, practical and effective. The e-module being developed is based on the 4D development model which consists of four stages, namely: define, design, develop, and disseminate.

In the first stage, namely define, a needs analysis is carried out, both in the form of needs, students, curriculum, and concepts, where at this stage an analysis of the conditions of learning that occurs before the research is carried out is carried out. This needs analysis is carried out to find out the problems and obstacles faced in the learning process, the aim is to create solutions that are in accordance with the conditions and conditions at school. The curriculum analysis carried out refers to the 2013 Curriculum. The subjects developed are Basic Catering for class $\mathrm{X}$ Catering students on the basic competencies of food processing techniques. Student analysis was carried out to see the abilities of students, background knowledge to thinking abilities of students. Concept analysis aims to see the basic competency concepts used in the development of discovery learning-based e-modules. Based on the concept analysis carried out, the indicators that will be used in e-module design based on discovery learning are obtained, namely understanding food processing techniques.

Furthermore, in the second stage, namely design, an e-module design is carried out by paying attention to the subjects that are in accordance with $\mathrm{KI}, \mathrm{KD}$, material and basic food learning objectives. The main activities of this stage are writing, analyzing, and editing e-modules which are designed with attention to language, word structure, objective format, evaluation and images, video, audio and animation. The e-module design is tailored to the results of the needs analysis, curriculum analysis, and student analysis. So that e-modules designed with Android Studio can be used on student smartphones anywhere and anytime.

The third stage is develop, making an e-module according to the validator's revisions and suggestions, so that an e-module is valid and feasible to be tested. In this third stage, the validity, reliability, practicality and effectiveness of the e-module were tested. A media can be said to be valid, if the results of the validity that are processed using the Aiken's V formula show a value that is in the valid interpretation range according to the provisions. Based on the validity test by the validator, the results of the material validity test are valid, this is an average of three aspects, namely the appearance aspect, the programming aspect, and the utilization aspect. Furthermore, the results of the material expert validity test obtained that the e-module was in the valid category based on an average of three aspects, namely aspects of curriculum, learning, and materials.

After the e-module is stated to be very practical according to the teacher and students, it is followed by testing the effectiveness of the e-module. A medium can be said to be effective through assessing student learning outcomes. With the provision that if there are differences in student learning outcomes after using learning media, the media is declared effective. There is a significant difference from the posttest scores of the control class and the experimental class based on the analysis using the $t$ test and seeing learning completeness classically. So it can be concluded that e-module based on discovery learning using the one that was designed was effective.

Through the use of e-modules in the learning process it can help students understand the material more quickly and increase the interaction between teachers and students because students already have provisions with the material discussed. E-modules developed with discovery learning-based learning models help students play a more active role in learning and are involved in learning. Discovery learning-based e-modules will provide text that is light to understand, as well as images that are closer to the real form of a component, helping students remember more easily when the original components are used. In addition to text and images that are easy to provide understanding for students, the videos available in the e-module also provide references for students in solving problems they find.

After the define, design and develop stages were carried out, the last stage the researchers did was the disseminate stage. At this stage, the e-modules that have been developed are distributed. Requirements for dissemination if the e-module being developed is valid, practical and effective from the validator and the trials that have been carried out.

\section{CONCLUSION}

The research resulted in an e-module based on discovery learning in the Basic Culinary subject. The content of the problem-based learning e-module that was developed consists of text, pictures, and videos. The e-module based on discovery learning that has 
been developed is online which can be used by students anytime and anywhere using a smartphone by downloading the application via the Playstore on Android. The e-module development process uses the 4D development model.

The research produces e-module based on discovery learning which is valid, practical, and effective. The results of the validity of the e-module are based on the responses of media experts and material experts in the valid category. The practicality of e-modules is seen based on the response of the subject teacher with a very practical category and based on the responses of students with a very practical category. The effectiveness of e-modules is seen based on the categorized effective student learning outcomes.

Student learning outcomes are seen based on classical completeness scores with the percentage categorized as effective. Based on the differences in learning outcomes of the control class and the experiment with the t-test, it was found that the class learning outcomes using e-module based on discovery learning were higher so that they were declared effective. Based on the gain-score test, the use of emodule learning based on discovery learning gives a moderate effect value.

Based on the results of the achievement of discovery learning-based e-module learning, the teacher should use it as an alternative in the learning process. So that e-modules can be developed in other materials and subjects, training should be carried out for teachers on how to make and use e-modules that are able to attract students to learn and give positive values to the use of smartphones. The expectation to be achieved from training for teachers can help teachers innovate more in creating learning resources that students can use anytime and anywhere and help in the availability of teaching materials at school. Not only teachers, there should be researchers who are willing to develop emodules to assist learning in other materials.

\section{REFERENCES}

Ahmad, Dharma Kasman. 2016. Trik Kolaborasi Android dengan PHP dan MySQL. Yogyakarta : Penerbit Lokomedia.

Anwar, Ilham. 2010. Pengembangan Bahan Ajar. Bahan Kuliah Online. Direktori UPI. Bandung.

B.P, Sitepu. 2006. Penyusunan Buku Pelajaran. Jakarta: Verbum Publishing.

Borg, Walter, R. 1989. Educational Research, an
Introduction. New York: Longman Icn.

Daryanto. 2013. Media Pembelajaran. Bandung: Satu Nusa.

Daryanto, Aris Dwicahyo, Pengembangan Perangkat Pembelajaran, Silabus, RPP, PHB, Bahan Ajar. 2014. Yogyakarta: Gava Media, h. 189-190.

Depdiknas. 2008. Penulisan Modul. : Direktorat Jendral Peningkatan Mutu dan Tenaga.

Djamarah, Syaiful Bahri dan Aswan Zain. 2002. Strategi Belajar Mengajar. Jakarta: Rineka Cipta.

Hamalik, Oemar. 2012. Proses Belajar Mengajar. Jakarta: PT Bumi Aksara.

Herlin, Febrina. 2011. Dasar dan Tujuan Disiplin Sekolah. Jakarta: PT. Tama Press.

Hudayah, Tri Erni., Luthfiyah, N., \& Wahini, M. 2014. Pengembangan Modul Menyiapkan Stock, Soup dan Sauce dengan Model Pembelajaran Langsung Untuk Siswa SMK Bidang Keahlian Tata Boga. Jurnal Pendidikan dan Vokasi: Teori dan Praktek (Vol.2, No.1)

Juwantara, R.A. 2019. Analisis Teori Perkembangan Kognitif Piaget pada Tahap Anak Usia Operasional Konkret 7-12 Tahun dalam Pembelajaran Matematika. Al-Adzka: Jurnal Ilmiah Pendidikan Guru Madrasah Ibtidayah, 9(1), 27-34

Kementrian Pendidikan Nasional. (2010). Panduan Pengembangan Modul Elektronik. Jakarta: Direktorat Jenderal Pendidikan Tinggi Majid.

Kemendikbud. 2017. Panduan Praktis Penyusunan eModul. Direktorat Pendidikan Dasar dan Menengah.

Komarasari, Riani Nirmala. 2016. Perancangan Modul Pembelajaran Prosedur Pembersihan dan Penataan Kamar Mandi Berbasis Discovery Learning di SMK Negeri 15 Bandung. Jurnal Universitas Pendidikan Indonesia.

Kurniasih, Imas \& Sani, Berlin. 2014. Implementasi Kurikulum 2013 Konsep \& Penerapan. Surabaya: Kata Pena.

Kurniawan, dkk. 2015. Efektifitas Penggunaan Jurnal Belajar Dikaji Dari Hasil Belajar dan Kemampuan Metakognisi dalam Pembelajaran Matematika. Jurnal Pendidikan Matematika. 2014. 1-8.

Laili, Ismi. 2020. Pengembangan E-Modul Project Based Learning pada Mata Pelajaran Instalasi Motor Listrik di SMK. Tesis tidak diterbitkan. Universitas Negeri Padang. 
Lestari, E. 2015. Pengaruh Penggunaan Bahan Ajar Online Terhadap Prestasi Siswa Universitas Terbuka Fakultas Ekonomi Universitas Terbuka. Jurnal Pendidikan Terbuka dan Jarak Jauh (Vol. 16, No.1)

Sugiyono. (2012). Metode Penelitian Pendekatan Kualitatif, Kuantitatif dan $R \& D$. Bandung : Alfabeta.

Suparman. (2014). Peningkatan Kemandirian Belajar dan Minat Belajar Siswa Mata Kuliah Elektronika Analog dengan Pembelajaran PBL. Jurnal Pendidikan Teknologi dan Kejuruan (Volume 22 No. 1), Hlm.84.

Suprihatiningrum, Jamil. 2013. Strategi Pembelajaran Teori dan Aplikasi. Yogyakarta: AR-RUZZ Media.

Syafitri, Festiyed, Putra, Mufit. 2019. Desain Modul Interaktif menggunakan Aplikasi Course Lab berbasis Pendekatan Saintifik Pada Materi Usaha, Energi, dan Momentum. Pillar of Physics Education, 12(3), 433-440.

Tumurun, S. 2016. Pengaruh Model Pembelajaran Discovery Learning Terhadap Keterampilan Berpikir Kreatif Siswa Pada Materi Sifat-Sifat Cahaya. Jurnal. Bandung: Universitas Pendidikan Indonesia. 